\title{
HAAPALAITE, A NEW NICKEL-IRON SULPHIDE OF THE VALLERIITE TYPE FROM EAST FINLAND
}

\author{
Maija Huhma, Y. Vuorelainen, T. A. Häkli and Heikki Papunen
}

Huhma, M., Vuorelainen, Y., Häkli, T. A. and Papunen, H. 1973: Haapalaite, a new nickel-iron sulphide of the valleriite type from East Finland. Buli. Genl. Soc. Finland 45, $103-106$.

\begin{abstract}
Haapalaite is a valleriite type mineral with the composition of $\left[\mathrm{Fe}_{1.26} \mathrm{Ni}_{.74} \mathrm{~S}_{2}\right]$ $1.610\left[\mathrm{Fe}_{, 16} \mathrm{Mg}_{84}(\mathrm{OH})_{2}\right]$. The mineral occurs as an accessory in a serpentinit : body in Finnish Northern Karelia about $33 \mathrm{~km} \mathrm{NNW}$ of the Outokumpu mine. Haapalaite is hexagonal with $\mathrm{a}_{0}=3.64 \AA$ and $\mathrm{c}_{0}=34.02 \AA$. The strongest lines of the X-ray powder pattern are 11.34 (003), $5.67(006), 1.841$ (10.15), and 1.821 (110).

The mineral shows a distinct pleochroism in reflected light; light brown to greyish brown. Anisotropism is strong; brown-red, greyish white. Its microhardness ranges from 9 to 11 with a $3 \mathrm{~g}$ load
\end{abstract}

Maija Hubma, Y. Vuorelainen and T. A. Häkli, Ouiokumpu Co., 02101 Tapiola, Finland.

Heikki Papunen, Institute of Geology, University of Turku, 20500 Turku 50, Finland.

\section{Introduction}

The serpentinites associated with the serpentinite-quartz rock series in the Outokumpu region frequently contain from 0.15 to 0.20 per cent nickel and less than one per cent sulphur (Huhma A. and Huhma M., 1970). Occasionally, the abundance of nickel attains somewhat higher values, i.e. up to $0.20-0.25$ per cent, although at the same time, the sulphur tenor may be as low as $0.2-0.7$ per cent.

In 1970, in connection with studies on the composition and mode of occurrence of the sulphides in ultramafic rocks, it was observed that some parts of the Kokka serpentinite
(Huhma A. and Huhma M., 1970, p. 61 and 65) were completely devoid of pyrrhotite and that pentlandite was the predominant sulphide. In addition to the latter, the rock was found to contain an unknown fox-red mineral which occured as small and thin scales with a strong metallic luster. The mineral was established as a new nickel-iron sulphide of the valleriite type and was named haapalaite after Dr. Paavo Haapala, Chief Geologist of the Outokumpu Company in recognition of his studies of serpentinites and nickel sulphide deposits in North Karelia and elsewhere. The mineral and the name have been approved by the Commission on New Minerals and Mineral Names. Type 
material is preserved at the Outokumpu Company, Tapiola, Finland.

\section{Occurrence}

The Kokka serpentinite body is situated about $33 \mathrm{~km} \mathrm{NNW}$ of Outokumpu (c. $63^{\circ} 1^{\prime}$ northern latitude and $28^{\circ} 50^{\prime}$ eastern longitude). Haapalaite occurs as an accessory mineral in the central part of a $300-400 \mathrm{~m}$ wide serpentinite lens which is mainly composed of chrysotile-lizardite. The other constituents are magnetite, chromite, chrome-bearing chlorite (clinochlore-sheridanite, kämmererite), pennine and occasionally carbonate. In addition to pentlandite and haapalaite, maucherite and chalcopyrite are met with sporadically as accessory sulphides.

Haapalaite is usually associated with bluish bundles of lizardite-chlorite in which it occurs as swarms of scales parallel to the serpentine sheets (Figs. 1 and 2). It has also been encountered together with carbonate but seldom with chrysotile.

\section{Chemistry}

Three electron microprobe determinations on haapalaite showed the composition to be fairly constant. Except for oxygen, all the elements were analysed by a Geoscan microanalyser using the following standards: pentlandite for $\mathrm{S}$, Ni, $\mathrm{Fe}$ and $\mathrm{Co}$, diopside for $\mathrm{Mg}$ and chalcopyrite for $\mathrm{Cu}$. The abundance of oxygen was determined by a Cameca microprobe using valleriite from Kaveltorp as a standard. The analytical data are compiled in Table 1.

The abundance of water was computed on the basis of the total oxygen content by assuming that $\mathrm{Ni}, \mathrm{Cu}$ and $\mathrm{Co}$ are incorporated in the sulphide layer as well as a part of the iron to make the metal to sulphur ratio $1: 1$ in a manner analogous to that observed in valleriite. The rest of the iron as well as aluminum and magne- sium were calculated to oxides. The remaining oxygen was presumed to be combined with hydrogen to form water.

Omitting the slight excess of water which remains when $\mathrm{H}_{2} \mathrm{O}$ is computed to $\mathrm{Mg}$, Fe $(\mathrm{OH})_{2}$, the analytical data suggest the formula

$$
\left[\mathrm{Fe}_{1.26} \mathrm{Ni}_{.74} \mathrm{~S}_{2}\right] 1.610\left[\mathrm{Fe}_{.16} \mathrm{Mg}_{84}(\mathrm{OH})_{2}\right]
$$

for haapalaite.

A comparison of the composition of haapalaite with that of valleriite (Table 1) reveals that not only has copper been replaced by nickel in the former, but that it also has a very low abundance of aluminum and calcium. On the other hand, the abundance of iron is higher in haapalaite than in valleriite and apparently a part of it forms oxide and is incorporated with $\mathrm{MgO}$ in the hydroxide layer.

\section{Table 1}

Electron microprobe analyses of haapalaite. $25 \mathrm{kV} / 100 \mu \mathrm{A}, \mathrm{LiF}$ and Mica crystals. For Oxygen: $10 \mathrm{kV} / 60 \mu \mathrm{A}$, L.S.D. crystal

\begin{tabular}{|c|c|c|}
\hline & Average & Range \\
\hline $\mathrm{Fe} \ldots \ldots \ldots \ldots \ldots$ & 29.10 & $28.8-29.4$ \\
\hline Ni $\ldots \ldots \ldots \ldots \ldots$ & 14.85 & $14.8-14.9$ \\
\hline $\mathrm{Cu} \ldots \ldots \ldots \ldots$ & 0.12 & \\
\hline Co $\ldots \ldots \ldots \ldots \ldots$ & 0.01 & \\
\hline $\mathrm{Mg} \ldots \ldots \ldots \ldots$ & 11.32 & $11.2-11.5$ \\
\hline $\mathrm{Al} \ldots \ldots \ldots \ldots$ & 0.08 & \\
\hline $\mathrm{Ca} \ldots \ldots \ldots \ldots \ldots$ & 0.00 & \\
\hline $\mathrm{S} \ldots \ldots \ldots \ldots \ldots$ & 22.04 & $21.6-22.4$ \\
\hline $\mathrm{O} \ldots \ldots \ldots \ldots \ldots$ & 21.20 & $21.0-21.4$ \\
\hline Total & 98.72 & \\
\hline
\end{tabular}

\begin{tabular}{|c|c|c|}
\hline & Haapalaite & $\begin{array}{c}\text { Valleriite } \\
\text { (Kaveltorp) } \\
\end{array}$ \\
\hline $\mathrm{Fe} \ldots \ldots \ldots \ldots \ldots$ & 24.13 & 21.2 \\
\hline $\mathrm{Ni} \ldots \ldots \ldots \ldots \ldots$ & 14.85 & - \\
\hline $\mathrm{Cu} \ldots \ldots \ldots \ldots$. & 0.12 & 17.6 \\
\hline Co $\ldots \ldots \ldots \ldots \ldots$ & 0.01 & 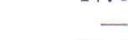 \\
\hline $\mathrm{s} \ldots \ldots \ldots \ldots$ & 22.04 & 21.4 \\
\hline $\mathrm{MgO} \ldots \ldots \ldots \ldots$ & 18.77 & 16.2 \\
\hline $\mathrm{Al}_{2} \mathrm{O}_{3} \ldots \ldots \ldots$ & 0.15 & 8.1 \\
\hline $\mathrm{CaO} \ldots \ldots \ldots \ldots$ & 0.00 & 1. 7 \\
\hline $\mathrm{FeO} \ldots \ldots \ldots \ldots$ & 6.39 & - \\
\hline $\mathrm{H}_{2} \mathrm{O}^{1} \ldots \ldots \ldots \ldots$ & 13.82 & 12.2 \\
\hline Total & 100.28 & 98.4 \\
\hline
\end{tabular}

$1 \mathrm{H}_{2} \mathrm{O}$ calculated

2 Valleriite (Evans and Allmann, 1968) 


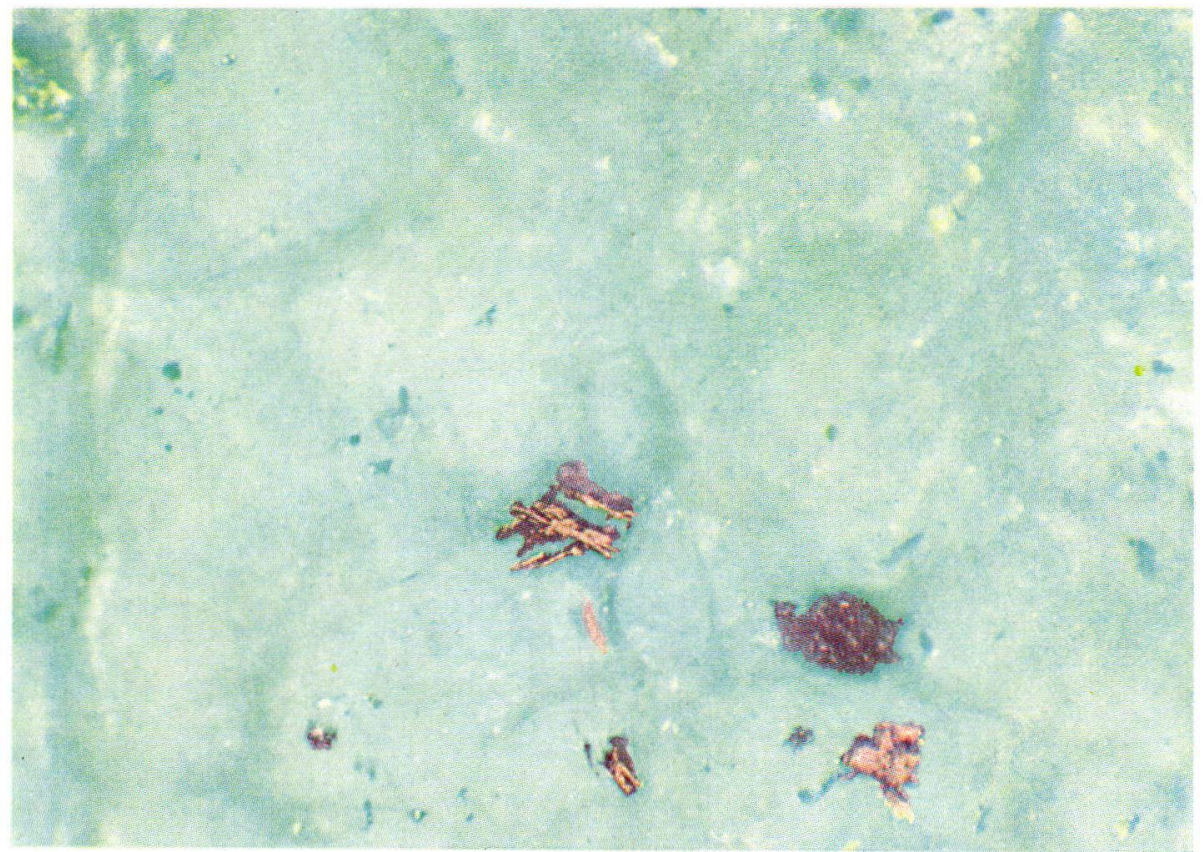

Fig. 1. Haapalaite crystals embedded in lizardite. Dark grains are chromite and magnetite. Magnification $100 \mathrm{x}$, oil immersion.

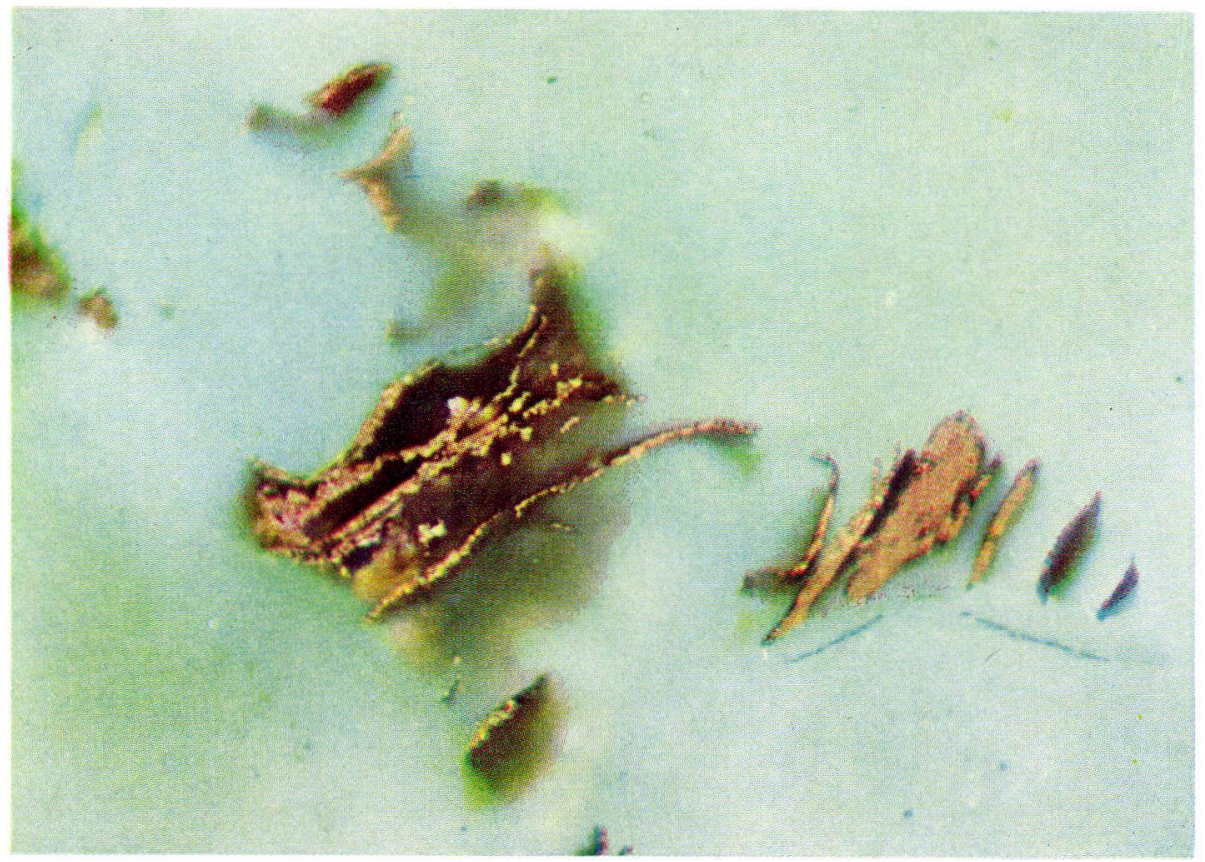

Fig. 2. A bundle on haapalaite scales in a section approximately perpendicular to c-axis. Magnification $500 \mathrm{x}$, oil immersion. 


\section{Crystallography}

The diffraction pattern of the mineral was studied by a powder method employing a camera and diffractometer techniques. The d-values are reported in Table 2. Several attempts were also made to obtain a single-crystal diffraction pattern. The precession photographs of hkOnets showed hexagonal symmetry and a value of $3.641 \AA$ for $a_{0}$ was measured. Owing to the distortion and smearing of the crystal plates, the photographs of the hOl and hhl nets were too diffuce for the exact determination of crystal geometry but the similarity with the corresponding nets of valleriite (Evans and Allmann, 1968) was evident. The $c_{0}=34.02 \AA$ was measured from a hOl-photograph. The lattice dimensions, especially $a_{0}$, seem to be somewhat reduced from those of the true valleriite as reported by Evans et al. (1964). The hkl-values presented in Table 2 were calculated on the basis of a hexagonal cell and measured lattice dimensions. Some values deviate from those of valleriite and the indexes are in reality more complicated because the structure seems to be a hybrid of sulphide and hydroxide layers resembling that of valleriite (Evans and Allmann, 1968).

\section{Physical and optical properties}

Under a binocular microcope the mineral is bronze-red in colour. In reflected light it appears brown with a distinct pleochroism from light brown to greyish brown. Anisotropy is very strong; bronze-red, greyish white.

All attempts to polish haapalaite grains well enough to warrant reliable reflectance measurements failed due to the softness of the mineral. The best polished sections indicated values clearly below those for valleriite and graphite.

The microindentation hardness, measured with a Reichert MHP device, ranges from 9 to 11 for a $3 \mathrm{~g}$ weight. Accordingly, the mean Vickers hardness is slightly less than that for graphite.

TABLE 2

$\mathrm{X}$-ray powder diffraction data of haapalaite and valleriite

Haapalaite

114. $6 \mathrm{~mm}$-diameter camera

$\mathrm{Mn}$-filtered $\mathrm{Fe}$ radiation

Hexagonal: $\mathrm{a}=3.64 \pm 0.02 \AA$, $c=34.02 \pm 0.02 \AA$

\begin{tabular}{|c|c|c|c|c|c|c|}
\hline hkl & $I$ & $d$ (cals) & $d$ (meas) & hkl & $I / I_{0}$ & $d$ (meas) \\
\hline 003 & vs & 11.34 & 11.34 & 003 & 100 & 1139 \\
\hline 006 & vs & 5.67 & 5.67 & 006 & 100 & 5.71 \\
\hline \multirow[t]{3}{*}{009} & vW & 3.78 & 3.78 & 009 & 50 & 3.80 \\
\hline & & & & 101 & 60 & 3.27 \\
\hline & & & & 012 & 50 & 3.23 \\
\hline 010 & sB & 3.16 & 3.18 & & & \\
\hline 013 & $\mathrm{D}$ & 3.04 & 3.00 & & & \\
\hline \multirow[t]{2}{*}{104} & & 2.96 & & 104 & 20 & 3.07 \\
\hline & & & & 015 & 10 & 2.958 \\
\hline 00.12 & w & 2. 835 & 2.835 & 00.12 & 50 & 2.846 \\
\hline 00.13 & $\mathrm{w}$ & 2.617 & 2.59 & & & \\
\hline 018 & vw & 2.535 & 2.532 & 018 & 10 & 2.604 \\
\hline 10.10 & $\mathrm{D}$ & 2.314 & 2.35 & 10.10 & 20 & 2.346 \\
\hline \multirow[t]{2}{*}{00.15} & wD & 2.268 & 2.268 & & & \\
\hline & & & & 01.11 & 20 & 2.259 \\
\hline 10.12 & D & 2.109 & 2.10 & & & \\
\hline \multirow[t]{3}{*}{10.13} & $\mathrm{w}$ & 2.015 & 2.014 & 10.13 & 20 & 2. 041 \\
\hline & & & & 00.18 & 50 & 1.885 \\
\hline & & & & 113 & 50 & 1.860 \\
\hline 10.15 & $\mathrm{~ms}$ & 1.842 & 1. 841 & & & \\
\hline 110 & $\mathrm{~ms}$ & 1.823 & 1.821 & & & \\
\hline \multirow[t]{3}{*}{114} & vw & 1.782 & 1.780 & & & \\
\hline & & & & 10.16 & 10 & 1.780 \\
\hline & & & & 00.21 & 10 & 1.629 \\
\hline 11.10 & w & 1.607 & 1.596 & & & \\
\hline 11.12 & vB & 1.533 & 1.532 & 208 & 10 & 1.526 \\
\hline
\end{tabular}

Etch reactions: $\mathrm{HNO}_{3}$ gives an instant iridescent tarnish, $\mathrm{HCl}$ tarnishes iridescent and $\mathrm{FeCl}_{3}$ stains dark brown. $\mathrm{KOH}, \mathrm{KCN}, \mathrm{H}_{2} \mathrm{O}_{2}$ and $\mathrm{HgCl}_{2}$ all show negative reactions.

Acknowledgment - The authors wish to express their gratitude to the Outokumpu Co. for the permission to publish this study.

\section{REFERENCES}

H. T. Evans Jr., C. Milton, E. C. T. Chao, I. Adler, C. Mead, B. Ingram and R. A. Berner (1964). Valleriite and the new iron sulfide, mackinawite. U.S. Geol. Survey Prof. Paper 475-D, D 64-D 69.

H. T. Evans Jr. and R. Allman (1968). The crystal structure and crystal chemistry of valleriite. Zeitschr. für Kristallographie, Bd. 127, 73-93.

Huhma, Aarto and Huhma, Maja (1970). Contribution to the geology and geochemistry of the Outokumpu region. Bull. Geol. Soc. Finland, 42, 57-88.

Manuscript received, January 4, 1973. 